\title{
ARTIKELEN
}

\section{'Ik verblijf in een gevangenis, daar is niets moreels aan.' Ervaren procedurele rechtvaardigheid bij binnenkomst in vreemdelingenbewaring.}

\author{
Nicolien de Gier, Mieke Kox, Miranda Boone \& Gabry Vanderveen
}

\section{Inleiding}

Om 8 uur's ochtends stapt Mohammad ${ }^{1}$ vanuit een cellenbusje Detentiecentrum Rotterdam (DCR) binnen. Hij wordt naar het binnenkomstloket gebracht waar een medewerker van de Dienst Justitiële Inrichtingen (DJI) hem bevraagt over onder meer zijn religieuze overtuigingen, rookgedrag en bagage. Zijn bagage wordt overgedragen aan een andere DJI-medewerker, waarna Mohammad piepvrij door een veiligheidspoort dient te lopen en in een afgesloten ruimte moet wachten. Hier haalt een andere DJI-medewerker Mohammad op om hem met behulp van een bodyscan op (inwendige) contrabande ${ }^{2}$ te controleren. Vervolgens wordt hij geregistreerd in het digitale systeem en worden een foto en vingerafdrukken van hem genomen. Bij het laatste bureau wordt Mohammads bagage gecontroleerd, kan hij telefoonnummers noteren en wordt zijn contante geld op een debetcard gezet die hij in het detentiecentrum voor telefoongesprekken en boodschappen kan gebruiken en die tevens als intern identificatiebewijs dient. Dan brengen twee DJI-medewerkers Mohammad naar zijn cel op de binnenkomstafdeling voor nieuwe vreemdelingen, waar een intakegesprek plaatsvindt.

Dit is de procedure die vreemdelingen doorlopen als zij 'ter fine van uitzetting' in vreemdelingenbewaring worden geplaatst. $^{3}$ Deze administratieve maatregel wordt gebruikt voor mensen - vreemdelingen genoemd - die op grond van artikel 8 van de Vreemdelingenwet 2000 (VW) onrechtmatig in Nederland verblijven, maar het land ondanks hun vertrekplicht niet verlaten. Het gaat hierbij onder meer om uitgeprocedeerde asielzoekers, mensen met een verlopen visum en arbeidsmigranten zonder verblijfsrecht. Circa 3800 vreemdelingen werden in 2019 vanuit een politiebureau, een asielzoekerscentrum (azc), een vrijheidsbeperkende (gezins)locatie, via de Koninklijke Marechaussee (Kmar) of vanuit een peni-

1 We gebruiken pseudoniemen in het gehele artikel.

2 Contrabande zijn voorwerpen die in justitiële inrichtingen verboden zijn voor gedetineerden en worden gezien als smokkelwaar, zoals drugs, wapens en mobiele telefoons.

3 Artikel 59 Vreemdelingenwet 2000. 
tentiaire inrichting (PI) naar een detentiecentrum overgebracht. ${ }^{4}$ Dit is formeel geen gevangenis, maar ademt wel de sfeer van een gevangenis door de justitiële gebouwelijke setting, het penitentiairrechtelijke regime en de sobere omstandigheden. ${ }^{5}$ Vreemdelingen verblijven circa drie dagen op de binnenkomstafdeling van het detentiecentrum voordat zij naar een verblijfsafdeling mogen. Bij voldoende zicht op uitzetting mogen zij in beginsel zes maanden in bewaring verblijven. Deze termijn kan na een rechterlijke toets verlengd worden met twaalf maanden. ${ }^{6}$ Gedurende het verblijf in vreemdelingenbewaring probeert de Dienst Terugkeer en Vertrek (DT\&V) de gedwongen uitzetting van de vreemdeling te realiseren. In 2018 slaagde dit bij $74 \%$ van de vreemdelingen. ${ }^{7}$

Vreemdelingenbewaring in Nederland is - net als in andere landen ${ }^{8}$ - herhaaldelijk bekritiseerd. Deze kritiek richt zich voornamelijk op het veelvuldige gebruik van de maatregel, de gevangenisachtige detentieomstandigheden, de lange detentieduur, herhaalde inbewaringstelling en het gebruik van strafrechtelijke sancties tijdens de inbewaringstelling. ${ }^{9}$ Deze zouden de fysieke en mentale gezondheid van vreemdelingen negatief beïnvloeden, waardoor vreemdelingen hun bewaring als zwaar ervaren. ${ }^{10}$ Behoudens uitzonderingen ${ }^{11}$ is er nog relatief weinig onderzoek gedaan naar de mate waarin vreemdelingen zelf de vreemdelingenbewaring

4 Ministerie van Justitie en Veiligheid, Rapportage Vreemdelingenketen. Periode januari-december 2019, Den Haag: Ministerie van Justitie en Veiligheid 2020.

5 Amnesty International, Het recht op vrijheid. Vreemdelingendetentie: het ultimum remedium, Amsterdam: Amnesty Nederland 2018a; Amnesty International, Geen cellen en handboeien! Het beginsel van minimale beperkingen in het regime van vreemdelingendetentie, Amsterdam: Amnesty Nederland 2018b.

6 Artikel 59 VW.

7 Ministerie van Justitie en Veiligheid, Rapportage Vreemdelingenketen. Periode januari-december 2018, Den Haag: Ministerie van Justitie en Veiligheid 2019. Het Ministerie van Justitie en Veiligheid heeft in zijn 'Rapportage Vreemdelingenketen 2019' geen vertrekcijfers vanuit vreemdelingenbewaring gerapporteerd.

8 M. Bosworth, Inside immigration detention, Oxford: Oxford University Press 2014; N. Fischer, 'The detention of foreigners in France: Between discretionary control and the rule of law', European Journal of Criminology 2013, 10(6), 692-708; E. Ryo, 'Fostering Legal Cynicism through Immigration Detention', Southern California Law Review 2017, 90, 999-1053.

9 Amnesty International 2018a, 2018b; G.N. Cornelisse, 'Handboeien en isoleercellen: over de gebrekkige implementatie van mensenrechten in vreemdelingenbewaring', Ars Aequi 2011, 339-344; De Nationale Ombudsman, Grenzen aan Vreemdelingenbewaring. Onderzoek naar de uitvoering van vreemdelingenbewaring, Den Haag: Nationale Ombudsman 2020.

10 Amnesty International, 2018a; Z. Steel, D. Silove, R. Brooks, S. Momartin, B. Alzuhairi \& I.N.A. Susljik, 'Impact of immigration detention and temporary protection on the mental health of refugees', The British Journal of Psychiatry 2006, 188(1), 58-64; M.H. Kox, 'De menswaardigheid van de vrijheidsontneming van vreemdelingen in Nederland', PROCES 2007, 5, 186-193; A.S. Leerkes \& M.H. Kox, 'Pressured into a preference to leave? A study on the "specific" deterrent effects and perceived legitimacy of immigration detention', Law \& Society Review 2017, 51(4), 895-929.

11 M. Bosworth, 'Can immigration detention centers be legitimate? Understanding confinement in a global world', in: K.F. Aas \& M. Bosworth (red.), The borders of punishment. Migration, citizenship, and social Exclusion, p. 149-165. Oxford: Oxford University Press 2013; Leerkes \& Kox 2017, 895-929; B. van Alphen, T. Molleman, A. Leerkes \& J. van den Hoek, Van bejegening tot vertrek. Een onderzoek naar de werking van vreemdelingenbewaring, Den Haag: Boom Lemma uitgevers 2013. Ryo 2017, 999-1053. 
legitiem achten. Dergelijke inzichten zijn echter om verschillende redenen van belang. Ten eerste is het voor een wetgever van belang inzicht te hebben in de mate waarin zijn wetgeving wordt geaccepteerd nu acceptatie bijdraagt aan de naleving van deze wetgeving en het realiseren van de doelstellingen. ${ }^{12}$ Het is voor de houdbaarheid van het vreemdelingenbeleid op langere termijn dan ook van belang te begrijpen in hoeverre dit beleid legitiem wordt gevonden door degenen die hieraan worden onderworpen. Ten tweede kan ervaren legitimiteit extra leedtoevoeging en negatieve invloed op iemands welzijn voorkomen ${ }^{13}$ en zo bijdragen aan een meer menswaardige vrijheidsontneming. Daarbij draagt ervaren legitimiteit van de - tenuitvoerlegging van een - vrijheidsontnemende maatregel bij aan orde en rust in een gevangenissetting, ${ }^{14}$ iets dat het leefklimaat in een inrichting voor zowel vreemdelingen als autoriteiten positief beïnvloedt. ${ }^{15}$ Ten derde is er voor de overheid een instrumentele prikkel om vreemdelingenbewaring zo in te richten dat de - tenuitvoerlegging van deze - vrijheidsontnemende maatregel door vreemdelingen legitiem wordt geacht. Hoewel een dergelijke instrumentele keuze voor legitiem beleid en/of de uitvoering van beleid ethische vragen oproept, blijkt uit onderzoek dat vreemdelingen in bewaring eerder bereid zijn aan hun gedwongen terugkeerproces mee te werken indien zij de bewaring legitiem achten. ${ }^{16}$

In deze bijdrage bespreken we daarom aan de hand van observaties en interviews met gedetineerde vreemdelingen in Detentiecentrum Rotterdam in hoeverre zij vreemdelingenbewaring legitiem achten. We focussen hierbij op de binnenkomstprocedure, een procedure die gemiddeld twee dagen duurt en loopt vanaf het moment dat de vreemdeling het detentiecentrum binnentreedt tot aan de plaatsing op een reguliere verblijfsafdeling. Deze fase - als onderdeel van het langere verblijf binnen vreemdelingenbewaring - is namelijk nog niet onderzocht terwijl uit eerdere studies blijkt dat eerdere ervaringen opvolgende ervaringen beïnvloeden. ${ }^{17}$ We bespreken in het vervolg van deze bijdrage eerst het rechtvaardigheidsconcept en de methode. Vervolgens beschrijven we in hoeverre vreemdelingen hun binnenkomstprocedure legitiem achten. We laten zien dat respondenten positief oordelen over de legitimiteit van de binnenkomstprocedure, maar dat hun legitimiteitsoordeel verandert als zij spreken over de inbewaringstelling op zichzelf. We sluiten af met een conclusie waarin we de implicaties van deze bevindingen voor het rechtvaardigheidsconcept bespreken en de bruikbaarheid van dit concept in de context van vreemdelingenbewaring in twijfel trekken.

12 T.R. Tyler, Why people obey the law, Yale University Press 2006.

13 A. Bottoms \& J. Tankebe, 'Beyond procedural justice: A dialogic approach to legitimacy in criminal justice', The journal of criminal law and criminology 2012, 102(1), 119-170; A. Liebling, L. Durie, A. Stiles \& S. Tait, 'Revisiting prison suicide: The role of fairness and distress', The effects of imprisonment 2005, 209-231.

14 R.F. Sparks, A.E. Bottoms \& W. Hay, Prisons and the Problem of Order, Oxford University Press 1996.

15 Ibid.

16 Leerkes \& Kox 2017, 895-929; Van Alphen et al. 2013.

17 K. van den Bos, R. Vermunt \& H.A.M. Wilke, 'Procedural and distributive justice: What is fair depends more on what comes first than what comes next', Journal of Personality and Social Psychology 1997, 72(1), 95-104; T.R. Tyler, Why people obey the law, Yale University Press 2006. 


\section{Rechtvaardigheid in vreemdelingenbewaring}

Legitimiteit betekent letterlijk 'wettelijk', 'gepast' of 'rechtvaardig'. ${ }^{18}$ Het heeft enerzijds een normatieve betekenis, namelijk of recht, beleid en praktijk juridisch toelaatbaar zijn op grond van vooraf vastgestelde criteria. ${ }^{19}$ Anderzijds heeft het concept een sociaalwetenschappelijke betekenis die verwijst naar iemands ideeën over - of ervaringen met - recht, beleid en praktijk. ${ }^{20}$ Beetham laat zien dat ervaren legitimiteit tot stand komt doordat er sprake is van (1) instemming met het gezag van de autoriteiten, (2) legaliteit ofwel ervaren conformiteit met de regels, en (3) gedeelde overtuigingen van gezagdragers en - in deze context vreemdelingen. ${ }^{21}$ Het wordt vaak aangenomen dat dergelijke legitimering, legaliteit en gedeelde overtuigingen direct samenhangen met onder meer ervaren procedurele, interactieve en/of distributieve rechtvaardigheid. ${ }^{22}$ Het concept procedurele rechtvaardigheid ziet op iemands ideeën over of ervaringen met het eerlijk uitoefenen van gezag door de autoriteiten. ${ }^{23}$ Dit wil zeggen dat juridische autoriteiten hun bevoegdheden en procedures eerlijk uitoefenen. ${ }^{24}$ Het betreft zowel de kwaliteit van besluitvorming als van de behandeling van mensen. ${ }^{25}$ Interactieve rechtvaardigheid verwijst naar iemands persoonlijke behandeling in diens ontmoetingen met de juridische autoriteiten en omvat informatieve, communicatieve en interpersoonlijke componenten. ${ }^{26}$ Distributieve rechtvaardigheid - of uitkomstrechtvaardigheid - betekent dat gelijkwaardige, eerlijke uitkomsten van belang zijn voor iemands rechtvaardigheidsgevoelens, ongeacht de wenselijkheid van de uitkomst. ${ }^{27}$ Tankebe - die onderzoek heeft gedaan naar de wijze waarop burgers de legitimiteit van politieoptredens in Ghana zien - vult bovenstaande vormen van rechtvaardigheid aan met effectiviteit, omdat autoriteiten die geen

18 A. Liebling \& J. Tankebe, 'Legitimacy and Criminal Justice', in: J. Tankebe \& A. Liebling (red.), Legitimacy and Criminal Justice, Oxford: Oxford University Press 2013, p. 1.

19 L. Noyon, 'Visies op legitimiteit', in: P. van Berlo, J.P. Cnossen, T.J.M. Dekkers, J.V.O.R. Doekhie, L. Noyon \& M. Samadi (red.), Over de grenzen van de discipline. Interactions between and within criminal law and criminology, Den Haag: Boom juridisch 2017, p. 147-165.

20 Noyon 2017, 147-165.

21 D. Beetham, The legitimation of power. Issues in political theory, Humanities Press International Inc. 1991.

22 J. Jackson \& B. Bradford, 'Blurring the distinction between empirical and normative legitimacy? A methodological commentary on "police legitimacy and citizen cooperation in China", Asian Journal of Criminology 2019, 14(4), 265-289; H.A. Grootelaar \& K. van den Bos, 'How Litigants in Dutch Courtrooms Come to Trust Judges: The Role of Perceived Procedural Justice, Outcome Favorability, and Other Sociolegal Moderators', Law \& Society Review 2018, 52(1), p. 234-268. Tyler 2006.

24 Tyler 2006.

25 Tyler 2006.

26 R.J. Bies, 'Interactional (in)justice: The sacred and the profane', in: J. Greenberg \& R. Cropanzano (red.), Advances in organizational justice, Stanford: Stanford University Press 2001, p. 85-108; K. van den Bos, 'Ervaren procedurele rechtvaardigheid in detentie', Tijdschrift voor Criminologie 2016, 58(1), p. 89-91.

27 J. Jackson, B. Bradford, M. Hough, A. Myhill, P.Quinton \& T.R. Tyler, 'Why do people comply with the law?: Legitimacy and the influence of legal institutions', British Journal of Criminology 2012, 52(6), p. 1051-1071; Van den Bos et al. 1997, p. 95-104. 
vertrouwen van hun burgers genieten in staat moeten zijn hun doelen te behalen om zo hun gezag te rechtvaardigen. ${ }^{28}$

$\mathrm{Nu}$ procedurele rechtvaardigheid als belangrijkste wordt gezien om tot ervaren legitimiteit in de westerse wereld te komen en er veel empirische steun voor dit concept bestaat, ${ }^{29}$ hebben wij in dit onderzoek op deze betekenis van rechtvaardigheid gefocust. We hebben deductief gekeken naar verschillende criteria die - in het bijzonder in een gevangenissetting - worden geacht bij te dragen aan ervaren procedurele rechtvaardigheid. ${ }^{30}$ Het eerste criterium is consistentie, ofwel de gelijke behandeling van mensen door de tijd heen. ${ }^{31}$ Het tweede criterium is neutraliteit, waarbij procedures en beslissingen vrij dienen te zijn van vooroordelen, ${ }^{32}$ iets dat in een gevangenissetting extra van belang wordt geacht. ${ }^{33}$ Tegelijkertijd kan neutraliteit in deze setting contraproductief werken als er geen - op eerlijke criteria gebaseerde - geïndividualiseerde uitzonderingen op de regel worden gemaakt. ${ }^{34}$ Derde criterium is de kwaliteit van besluitvorming, waarbij procedures accuraat en inzichtelijk dienen te zijn, bijvoorbeeld door een adequate informatievoorziening. Dit ziet op de kwaliteit en het onderbouwen van beslissingen, nu kwalitatief goede beslissingen het vertrouwen in de autoriteit ten goede komen. ${ }^{35}$ Een vierde criterium is de mogelijkheid tot inspraak, zodat mensen de mogelijkheid hebben om oneerlijke of onjuiste beslissingen te corrigeren. ${ }^{36}$ Daarbij is het zeker in een gevangeniscontext van belang dat deze inspraak gehoord en serieus genomen wordt. ${ }^{37}$ Vijfde criterium is belangbehartiging, waarbij alle betrokken partijen op elk moment in het besluitvormingsproces de mogelijkheid hebben om hun belangen te behartigen. ${ }^{38}$ Het laatste criterium behelst een respectvolle bejegening, waarbij procedures dienen te voldoen aan algemene ethische en morele standaarden. ${ }^{39}$ Dit betekent dat mensen - en zeker mensen wier vrijheid is ontnomen - respectvol en waardig worden behandeld. ${ }^{40}$ Criminology 2009, 47(4), p. 1265-1293. Beetham 1991; Jackson \& Bradford 2019, 265-289.

29 Tyler 2006; J. Tankebe, 'Viewing things differently: The dimensions of public perceptions of police legitimacy', Criminology 2013, 51(1), p. 103-135. Zie echter Kox, in ontwikkeling.

30 Tyler 2006; Tankebe 2013, 103-135.

31 G.S. Leventhal, 'What should be done with equity theory? New approaches to the study of fairness in social relationships', in: K. Gergen (red.), Social exchange: Advances in theory and research, New York: Plenum Press 1980, p. 27-55.

32 Leventhal 1980, 27-55.

33 T.R. Tyler, 'Legitimacy in corrections. Policy implications', Criminology and Public Policy 2010, 9(1), 127-134.

34 M. Boone \& M. Kox, 'Neutrality as an element of perceived justice in prison: consistency versus individualization', Utrecht Law Review 2014, 10(4), 118-130.

35 Leventhal 1980, 27-55; Tyler 2010, 217-134.

36 Idem.

37 Tyler 2010, 127-134.

38 Leventhal 1980, 27-55.

39 Idem.

40 Tyler 2010, 127-134. 
In de gevangeniscontext wordt daarnaast nog extra belang gehecht aan communicatie, mede wegens de langdurige relaties tussen gedetineerden en bewakers. ${ }^{41}$ Daarnaast hebben we inductief gekeken of andere criteria van invloed zijn op de legitimiteitspercepties van vreemdelingen in bewaring. Het belang van procedurele rechtvaardigheid om tot legitimiteit te komen wordt namelijk wel breed gedragen in de wetenschappelijke literatuur, ${ }^{42}$ maar uit eerder onderzoek blijkt dat vreemdelingen de legitimiteit van vreemdelingenbewaring ter discussie stellen zonder daarbij specifiek naar procedurele ervaringen te verwijzen. ${ }^{43} \mathrm{Zo}$ toont Ryo aan dat vreemdelingen in vreemdelingenbewaring in de Verenigde Staten de legitimiteit betwisten vanwege het punitieve karakter van deze administratieve maatregel. Dit uit zich onder meer in de sobere omstandigheden, de bejegening, de voor hen onoverzichtelijke - en ondoorgrondelijke - juridische positie en de ervaren willekeur gedurende hun detentie. ${ }^{44}$ Bosworth stelt dat vreemdelingenbewaring in Groot-Brittannië met een legitimiteitstekort kampt gezien het gebrek aan gedeelde overtuigingen, waarden en verwachtingen tussen vreemdelingen en autoriteiten. ${ }^{45}$ Dit wordt mede ingegeven door uiteenlopende opvattingen over burgerschap. ${ }^{46}$ Ook vreemdelingen in vreemdelingenbewaring in Nederland geven aan hun vrijheidsontneming niet te begrijpen. ${ }^{47}$ Zij geven aan dat zij hun opsluiting - waarbij zij verblijven onder sobere omstandigheden en beperkte autonomie en vrijheid genieten - niet verdienen, iets dat Leerkes en Kox omschrijven als 'the pain of perceived illegitimacy'. ${ }^{48}$ De opvattingen van vreemdelingen - en de motivering van deze opvattingen - lopen echter uiteen en worden mede ingegeven door migratiemotief, inbedding in Nederland en huidige aspiraties. ${ }^{49}$ Tot slot blijkt uit gevangenisonderzoek dat naast ervaren procedurele rechtvaardigheid ook een veilige leefomgeving en investeringen voor het leven na detentie belangrijk zijn om in een dergelijke setting tot ervaren legitimiteit te komen. ${ }^{50}$ In deze bijdrage willen we voortbouwen op deze studies door in beeld te brengen hoe vreemdelingen in vreemdelingenbewaring de - uitvoering

41 D. Franke, D. Bierie \& D.L. MacKenzie, ,Legitimacy in corrections: A randomized experiment comparing a boot camp with a prison', Criminology and Public Policy 2010, 9(1), 89-117; A.E. Bottoms, 'Interpersonal violence and social order in prisons', in: M.H. Tonry \& J. Petersilia (red.), Prisons, Crime, and Justice: An Annual Review, Chicago, IL: University of Chicago Press 1999; R. Sparks, A. Bottoms \& W. Hay, Prisons and the Problem of Order, Oxford: Clarendon 1996; Tyler 2010, 127-134.

42 Jackson \& Bradford 2019, 265-289; Tankebe, 2013; Tyler 2006.

43 Zie bijvoorbeeld Ryo 2017, 999-1053; Bosworth 2013, 149-165; Leerkes \& Kox 2017, 895-929; Alphen et al. 2013. Zie ook Kox in ontwikkeling.

44 Ryo 2017, 999-1053.

45 Bosworth 2013, 149-165.

46 Idem.

47 Leerkes \& Kox 2017, 895-929.

48 Idem. Dit onderzoek is in 2011 uitgevoerd. Sindsdien zijn de detentieomstandigheden veranderd. Zo is het programma voor vreemdelingen uitgebreid en hebben zij meer interne vrijheden verkregen.

49 Leerkes \& Kox 2017, 895-929. Zie ook Kox in ontwikkeling.

50 Franke et al. 2010, 89-117; Bottoms 1999; S. Hulley, A. Liebling \& B. Crewe, B. 'Respect in prisons: Prisoners' experiences of respect in public and private sector prisons', Criminology \& Criminal Justice 2012, 12(1), 3-23; Sparks et al. 1996, 127-134; Tyler 2010, 127-134. 
van de - binnenkomstprocedure ervaren in termen van zowel procedurele rechtvaardigheid als legitimiteit.

\section{Methode}

De eerste auteur heeft in het kader van haar afstudeeronderzoek in 2019 de data verzameld en geanalyseerd. Zij onderzocht in hoeverre gedetineerde vreemdelingen zich procedureel rechtvaardig behandeld voelen tijdens de binnenkomstprocedure in DCR. Hiervoor is gebruik gemaakt van een documentanalyse, observaties en semigestructureerde interviews met vreemdelingen in vreemdelingenbewaring. Er is voor het DCR gekozen nu hier in 2019 de meeste vreemdelingen waren gedetineerd. Dit betrof enkel mannen; vrouwen, gezinnen en alleenstaande minderjarige vreemdelingen worden minder vaak gedetineerd en verbleven ten tijde van het onderzoek allen in detentiecentrum Zeist. De toegang tot het detentiecentrum is verkregen via de contacten van de tweede auteur, ${ }^{51}$ waarna tijdens een voorgesprek met de directiesecretaris van het detentiecentrum concrete afspraken over de uitvoering van het onderzoek zijn gemaakt.

\section{Vooronderzoek: documentanalyse en drie observaties}

Eerst is de binnenkomstprocedure in kaart gebracht op basis van een analyse van verschillende documenten, zoals de interne reglementen en de personeelsinstructies met daarin de werkwijze aangaande de binnenkomstprocedure. Dit is aangevuld met observaties van drie binnenkomstprocedures en heeft geleid tot een Engels- en Nederlandstalige infographic (zie figuur 1). Deze infographic diende als hulpmiddel tijdens de interviews, om eventuele taalbeperkingen te ondervangen en om het doel en onderwerp van het onderzoek te kaderen.

51 Mieke Kox heeft eerder onderzoek in dit detentiecentrum uitgevoerd. Zie bijvoorbeeld M.H. Kox, 'Leaving detention... A study on the influence of immigration detention on migrants' decision making processes regarding return, Den Haag: Internationale Organisatie voor Migratie 2011; M.H. Kox, M. Boone \& R.H.J.M. Staring, 'The pains of being unauthorized in the Netherlands', Punishment and Society 2020, 1, 22(4), 534-552. DOI: 10.1177/1462474519887357. 
Figuur 1 De binnenkomstprocedure in beeld ${ }^{52}$

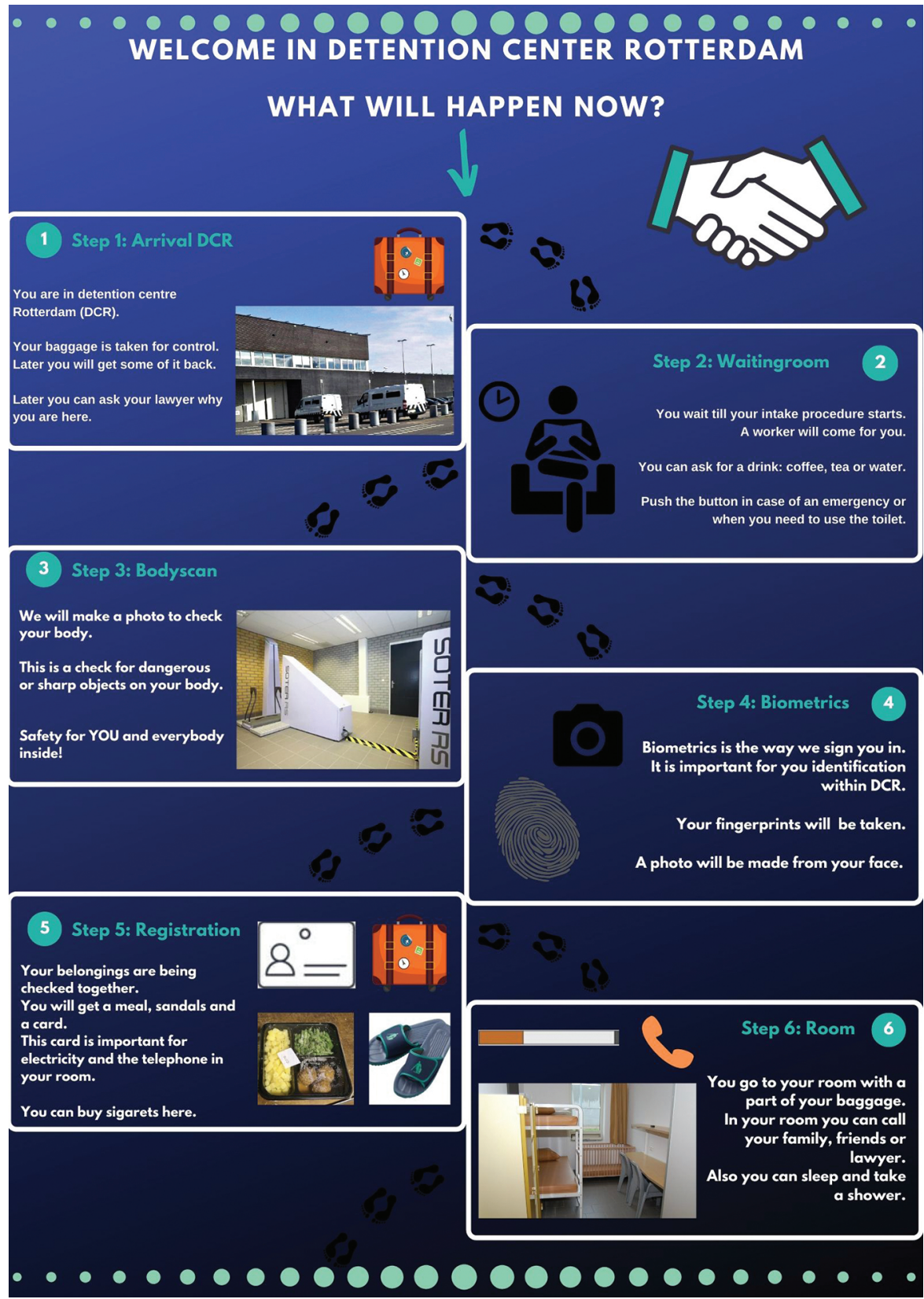

52 Vanuit DCR bestaat het voornemen om deze infographic in de wachtruimtes op te hangen om vreemdelingen zo al in dit stadium te informeren over de binnenkomstprocedure die gaat volgen. 


\section{Observaties en interviews}

Na dit vooronderzoek zijn de binnenkomstprocedures van 57 vreemdelingen vanaf het moment van binnenkomst tot aan de plaatsing op de binnenkomstafdeling geobserveerd. Alle vreemdelingen die tussen 20 mei en 30 augustus 2019 op grond van artikel 59 VW het detentiecentrum werden binnengebracht, zijn direct bij het ontvangstloket benaderd voor geanonimiseerde deelname aan het onderzoek. De onderzoeker lichtte het onderzoek toe en liet haar studentenkaart zien om haar onafhankelijkheid te benadrukken. Wanneer de vreemdeling instemde met het verzoek, is de gehele binnenkomstprocedure van desbetreffende vreemdeling gevolgd. Nadien zijn deze vreemdelingen - indien nog aanwezig in DCR op hun cel benaderd en zijn uiteindelijk veertig van hen in de spreekkamers van het DCR geïnterviewd. ${ }^{53}$ De observaties leidden tot scherpere interviews waarbij respondenten konden worden bevraagd over hetgeen was geobserveerd en over eventuele inconsistenties tussen observaties en beschreven ervaringen. Deze datatriangulatie heeft geresulteerd in diepgaandere inzichten.

De spreekkamers vormden een stille, afgezonderde ruimte, welke de concentratie van zowel interviewer als respondent en de daaruit voortvloeiende betrokkenheid ten goede kwam. De interviews waren semigestructureerd, waardoor de mogelijkheid ontstond om - naast het voorleggen van de vragen - stil te staan bij de persoonlijke verhalen van de respondenten. In een later - informeel - gesprek vertelden veel respondenten dat de aandacht voor hun persoonlijke situatie hen goed had gedaan en spraken zij hun waardering hierover uit. De interviews zijn grotendeels in het Nederlands en Engels afgenomen, maar bij drie respondenten is gebruik gemaakt van een medegedetineerde om te vertalen. Nadat saturatie was bereikt, is het veldwerk beëindigd. Deze aanpak heeft geresulteerd in een onderzoeksgroep die wordt gekenmerkt door een grote diversiteit aan nationaliteiten, leeftijden, familiesituaties, sociale inbedding en economische situaties.

Tijdens de observaties en interviews is gelet op de - in het theoretisch kader genoemde - aspecten van rechtvaardigheid zoals aangedragen door Leventhal en Tyler, namelijk consistentie, neutraliteit, kwaliteit van besluitvorming, adequate informatievoorziening, inspraak, belangenbehartiging, en respect en waardigheid in de bejegening. ${ }^{54}$ Deze criteria zijn op basis van de eerder besproken onderzoeken van Leventhal en Tyler ${ }^{55}$ geoperationaliseerd. Ter illustratie is het criterium 'inspraak' geoperationaliseerd als de inspraak die de vreemdeling heeft tijdens de binnenkomstprocedure en de mogelijkheid om fouten te herstellen. ${ }^{56}$ Geobserveerd is of de respondent betrokken werd bij de besluitvorming en de mate waarin deze inspraak gehoord en serieus genomen werd door de DJI-medewerkers. Tijdens het interview is de respondent gevraagd naar de mate waarin hij vond dat hij inspraak had en hoe dat volgens hem tot uiting kwam, in hoeverre hij

53 Er was geen sprake van non-respons, maar zeventien respondenten waren binnen een paar dagen uitgezet of vrijgelaten waardoor zij niet meer geïnterviewd konden worden.

54 K. Beijersbergen, Procedural justice in prison: a study on determinants and consequences of a procedurally just treatment of prisoners (diss. Amsterdam VU), Amsterdam: Vrije Universiteit Amsterdam 2014; Van den Bos 2016, 89-91; Leventhal 1980, 27-55; Tyler 2010, 127-134.

55 Leventhal 1980, 27-55; Tyler 2010, 127-134.

56 Leventhal 1980, 27-55; Tyler 2010, 127-134. 
het idee had dat hij werd gehoord en waarom deze mate wel of niet voldoende voor hem was. De observaties zijn uitgewerkt in veldnotities en de interviews zijn met toestemming van de respondent opgenomen en verbatim getranscribeerd. ${ }^{57}$ Alle data zijn geanalyseerd met MAXQDA, kwalitatieve data-analysesoftware. Hierbij is zowel deductief als inductief gewerkt; gekeken is in hoeverre de in de literatuur bekende criteria en eventuele aanvullende criteria samenhangen met de opvattingen van de respondenten over de ervaren rechtvaardigheid van de binnenkomstprocedure.

\section{Ervaren rechtvaardigheid van de binnenkomstprocedure}

De documentanalyse en observaties laten zien dat de binnenkomstprocedure uit meerdere fases bestaat die alle respondenten in dezelfde volgorde doorlopen. Zoals geschetst in de inleiding worden zij na aankomst met de cellenbus en ontvangst bij het loket door DJI-medewerkers achtereenvolgens begeleid naar de wachtruimte, bodyscan, biometrie, registratiebalie en hun cel op de binnenkomstafdeling. ${ }^{58}$ In deze paragraaf beschrijven we aan de hand van deze verschillende stappen dat de respondenten de procedure doorgaans rechtvaardig vinden. Zij baseren zich enerzijds op de criteria bekend uit de procedurele rechtvaardigheidsliteratuur, anderzijds op nieuwe, aanvullende criteria waaraan zij meer waarde lijken te hechten. Ondanks het positieve oordeel over de rechtvaardigheid van de binnenkomstprocedure vindt het merendeel van de respondenten de inbewaringstelling onverdiend. Zij stellen de legitimiteit hiervan ter discussie. Dit laat zien dat de focus op enkel de - uitvoering van de - binnenkomstprocedure te beperkt is om de legitimiteitspercepties van vreemdelingen over hun bewaring te begrijpen.

\section{Het belang van bekende procedurele rechtvaardigheidscriteria}

Het onderzoek laat zien dat respondenten overwegend positief oordelen over de procedurele rechtvaardigheid van de binnenkomstprocedure als we kijken naar de criteria die centraal staan in de procedurele rechtvaardigheidsliteratuur en in het theoretisch kader zijn beschreven. De respondenten benadrukken het belang van deze criteria en geven bijvoorbeeld aan het belangrijk te vinden dat besluiten eerlijk tot stand komen en dat zij hier adequaat over worden geïnformeerd. Ook tijdens de observaties blijkt dat respondenten die vanuit een PI bij het ontvangstloket aankomen rustig en duidelijk geïnformeerd het detentiecentrum binnenkomen, wellicht omdat medewerkers van de DT\&V en DJI tijdens hun verblijf in de PI al herhaaldelijk met hen hebben gesproken over het uitzettingstraject dat hen vanuit vreemdelingenbewaring te wachten staat. Dit staat in schril contrast met respondenten die vanuit een azc of politiebureau worden binnengebracht. Hoewel deze respondenten wellicht ook informatie over de inbewaringstelling ontvangen 
hebben voordat zij naar het detentiecentrum werden gebracht, lijken zij onvoldoende adequaat geïnformeerd over - de reden voor en ingangstermijn van - hun inbewaringstelling. Zij ogen emotioneler en angstiger, wat zich uit in huilbuien, uitspraken van frustratie of extreme teruggetrokkenheid. De betreffende respondenten vertellen dat zij - mede gezien het naast DCR gelegen vliegveld - vreesden dat zij direct uitgezet zouden worden en hierdoor geschokt waren. Zij vertellen dat ze gekalmeerd werden door de respectvolle bejegening - blijkende uit de persoonlijke aandacht die zij ontvingen - van en uitleg over de reden van inbewaringstelling door de DJI-medewerkers. ${ }^{59}$ Een 23-jarige Afghaanse respondent afkomstig van een politiebureau vertelt bijvoorbeeld dat de agenten op het bureau hem nauwelijks aanspraken waardoor het hem niet duidelijk was dat hij in vreemdelingenbewaring werd geplaatst:

'It was crazy you know. I didn't know I was going to prison. [...] But the guard [DJI-medewerker] told me everything was okay and she helped me calm down by explaining it to me. I think that's good.' - Rashid.

Dit laat niet alleen het belang van de adequate informatievoorziening en een respectvolle bejegening zien, het bevestigt ook dat opvattingen over de rechtvaardigheid van de binnenkomstprocedure moeten worden gezien in het licht van opvattingen over eerdere ervaringen met verschillende autoriteiten. ${ }^{60}$

$\mathrm{Na}$ aankomst en registratie bij het loket worden vreemdelingen naar de wachtruimte begeleid. Hier werd het belang van consistentie in de toepassing van de regels om tot een rechtvaardig ervaren binnenkomstprocedure te komen duidelijk. IBS'ers ${ }^{61}$ - die in tegenstelling tot de andere binnengebrachte vreemdelingen nog in afwachting zijn van een eventuele beslissing tot inbewaringstelling - moeten door organisatorische regelingen namelijk geregeld dagdelen in de wachtruimte doorbrengen, terwijl later binnengebrachtevreemdelingen die al wel formeel in bewaring zijn gesteld eerder worden opgeroepen voor de binnenkomstprocedure. Uit de observaties blijkt dat deze IBS'ers niet op de hoogte waren van hun andere juridische positie die maakte dat ze langer moesten wachten. Zij vroegen dan ook regelmatig aan DJI-medewerkers waarom anderen eerder werden opgeroepen terwijl zij al langer wachtten. Ook uit de interviews blijkt dat zij deze inconsistentie oneerlijk vinden en dat dit tot onzekerheid leidt. Zo vertelt een 29jarige Bengalese IBS'er:

'I don't know why they keep me here so long. I say to the security "I'm in long time". There is probably six people who went for me. But I came in first at the reception. I don't understand, it's unfair.' - Abir.

61 IBS staat voor In Bewaring Stellen. IBS'ers zijn op het moment van binnenkomst nog niet officieel in bewaring gesteld en in afwachting van een formeel besluit tot inbewaringstelling. 
Deze IBS'er heeft - net als meerdere IBS'ers - het idee dat andere vreemdelingen worden bevoordeeld ten koste van hem. Hoewel er in dit voorbeeld sprake is van consistente toepassing van de geldende regelgeving en de verschillende wachttijden het gevolg van organisatorische processen zijn, is dit voorafgaand aan de binnenkomst onvoldoende adequaat uitgelegd aan desbetreffende vreemdelingen waardoor dit ten koste gaat van de ervaren kwaliteit van de besluitvorming. Dit bevestigt nogmaals het belang van adequate informatievoorziening, iets dat ook blijkt uit het gebrek aan een klok in de wachtruimte waardoor respondenten hun tijdsbesef kwijtraken en het wachten gevoelsmatig langer duurt.

In de wachtruimte komt ook de toegevoegde waarde van een respectvolle behandeling vanuit de autoriteiten naar voren, in de vorm van persoonlijke aandacht, positieve bejegening en interesse. ${ }^{62}$ De respondenten beschouwen dit als een vorm van respect. Zij definiëren respect enerzijds als beleefde, wederkerige, omgangsvormen die zij bij de DJI-medewerkers voelen. Anderzijds als de mogelijkheid om - in de woorden van Hulley en collega's - iets voor elkaar te krijgen. ${ }^{63}$ Dit wil zeggen dat DJI-medewerkers vreemdelingen (helpen te) voorzien in hun praktische behoeften en bijdragen aan het persoonlijk welzijn en de belangenbehartiging - een ander bekend rechtvaardigheidscriterium - van de vreemdelingen. Dit laatste komt bijvoorbeeld naar voren bij een respondent die angstig het detentiecentrum binnenkwam waarna een DJI-medewerker hem apart nam in de wachtruimte, informeerde over de inbewaringstelling, koffie aanbood en regelmatig informeerde hoe het ging. De respondent vertelt hier verder over:

'Ik was bang, maar hij maakte mij blij. Ze [DJI-medewerkers] behandelden mij als een normaal mens. Ik dacht ze gaan slecht praten, omdat ik opgesloten zit. Ze zorgden voor mij en ik werd rustiger. Dat vond ik wel goed.' - Mohammed.

Deze respectvolle bejegening en de belangenbehartiging waarbij oog is voor het persoonlijke welzijn van de gedetineerden wordt door de respondenten gewaardeerd. Zij hebben dit gedurende de gehele binnenkomstprocedure ervaren. Vanuit de wachtruimte worden vreemdelingen naar de bodyscan begeleid. Hier komt het belang van - zij het begrensde - inspraak en kwalitatieve besluitvorming tijdens de binnenkomstprocedures aan bod, criteria die zowel Leventhal als Tyler noemt. ${ }^{64}$ Zo blijkt tijdens de observaties dat de respondenten mogen kiezen tussen visitatie of een bodyscan. Zij dienen hiervoor een - in meerdere talen vertaald - toestemmingsformulier te ondertekenen waarop onder meer de gezondheidsrisico's van de röntgenstraling van de bodyscan staan vermeld. Uit gesprekken met de DJI-medewerkers blijkt dat dit apparaat door de overheid als humaner alternatief voor visitatie is ingesteld, omdat vreemdelingen zich op deze wijze niet hoeven te ontkleden. Respondenten benoemen het belang van de informatie op het toestemmingsformulier en waarderen de mogelijkheid om mid- 
dels hun keuze inspraak te hebben in hun procedure, ondanks de beperkte keuzemogelijkheden die zij tot hun beschikking hebben. Dit draagt volgens hen ook bij aan de door hen ervaren eerlijke, kwalitatieve besluitvorming. Zo ook een 21jarige Guyaanse respondent:

'Ze geven je een formuliertje en na het lezen, vraagt hij of je akkoord gaat, zodat ze de bodyscan mogen uitvoeren. Ik vind dat heel goed, want ze houden rekening met je. Sommigen willen namelijk geen bodyscan en dat kun je zelf aangeven. Dan heb je zelf ook invloed op de beslissing.' - Miguel.

Het belang van inspraak - en tevens dat van een respectvolle bejegening - blijkt eveneens bij de registratie van de vreemdelingen in het detentiecentrum, een stap die na de bodyscan en biometrie plaatsvindt. Hier kunnen de respondenten vragen stellen en hun persoonlijke eigendommen controleren. De observaties laten zien dat DJI-medewerkers de tijd nemen om vragen te beantwoorden en uitleg te geven over praktische zaken, waardoor respondenten zichtbaar rustiger worden, minder druk praten en minder boosheid of onvrede over de inbewaringstelling uiten. Het valt overigens op dat respondenten aangeven voldoende mogelijkheden tot inspraak te hebben maar hier niet altijd gebruik van wensen te maken. Dit is enerzijds vanwege gevoelde loyaliteit ten opzichte van de DJI-medewerkers of een moreel plichtsbesef om de autoriteiten te volgen. Een 33-jarige respondent uit Nigeria vertelt bijvoorbeeld dat hij in Nederland asiel heeft aangevraagd en daarom de overheid van Nederland veel verschuldigd is. Uit loyaliteit heeft hij geen gebruik gemaakt van de mogelijkheid tot inspraak, hoewel hij er naar eigen zeggen wel de mogelijkheid toe had. Anderzijds vertelde een respondent geen gebruik te maken van de mogelijkheid tot inspraak vanwege eerdere negatieve ervaringen dat er niets werd gedaan met zijn inspraak. Deze 21-jarige man uit Afghanistan vertelt dat hij tijdens zijn overplaatsing uit het azc geen mogelijkheid tot inspraak had, omdat de politie zijn vragen negeerde. Hij heeft zich daarom in DCR bewust niet uitgesproken omdat hij dacht dat het wederom geen verschil zou maken. Inspraak is dus ook in deze context van belang om tot een eerlijke binnenkomstprocedure te komen, maar dit wil niet zeggen dat vreemdelingen ook daadwerkelijk gebruik maken van deze mogelijkheid. ${ }^{65}$

Hierna worden vreemdelingen naar hun cel gebracht op de binnenkomstafdeling, door DJI-medewerkers ook wel 'opvoedafdeling' genoemd, omdat de vreemdelingen hier aan een strikter regime worden onderworpen en er meer aandacht is voor het uitleggen van gedragsnormen, leefregels en de persoonlijke situatie van de vreemdeling. Mede hierom vindt een intakegesprek plaats tussen de vreemdeling en DJI-medewerker. De DJI-medewerker geeft bij dit gesprek uitleg over de veiligheid en omgangsnormen in de inrichting en controleert of de vreemdeling het gebruik van de faciliteiten begrijpt en voldoende levensmiddelen - als kleding en geld - tot zijn beschikking heeft. Het valt op dat er veel interactie plaatsvindt tijdens dit gesprek. Hoewel het spreken over 'opvoeding' van volwassen vreemdelingen vragen kan oproepen en enigszins paternalistisch kan overkomen, vertel- 
len respondenten de persoonlijke aandacht en adequate informatievoorziening over de gedragsnormen en dagindeling te waarderen en als vorm van respect te ervaren. Een 26-jarige Italiaanse respondent vertelt:

'They come to give you the rules about how we live here, how to behave in your room. No writing on the wall, you need to respect everyone. It's good to know for me and for the center. [...] You know what to expect and how to behave. That's important for order, and therefore for safety.' - Osis.

Daarnaast beschrijven de respondenten op de binnenkomstafdeling het zowel door Liebling ${ }^{66}$ als Boone en Kox $^{67}$ geconstateerde spanningsveld tussen een neutrale, consistente toepassing van regels enerzijds en een geïndividualiseerde behandeling anderzijds. Zo vertellen respondenten het goed te vinden dat de DJImedewerkers hen naar hun idee op eenzelfde manier en met dezelfde rechten behandelen tijdens hun bewaring. Echter, meerdere respondenten benadrukken dat niet alle ingeslotenen hetzelfde zijn nu een deel van de ingesloten vreemdelingen een strafblad heeft. Dit zijn voornamelijk respondenten die - naar eigen zeggen - zelf niets 'crimineels' hebben gedaan en bang zijn voor vreemdelingen afkomstig uit een PI. Een Libanese respondent verwoordt deze overtuiging als hij vertelt dat hij bang is als de celdeur op slot gaat nu hij zijn cel met een vreemdeling met een strafrechtelijk verleden deelt. Hij vindt dat er verschil is tussen vreemdelingen zonder en met een strafblad en dat zij niet samen op cel geplaatst zouden mogen worden. Hij meent dat het crimineel verleden stengere regels voor de laatstgenoemde groep zou rechtvaardigen en dat dit zou bijdragen aan zijn veiligheidsgevoel. Desalniettemin is de meerderheid van de geïnterviewde vreemdelingen positief over de rechtvaardigheid van de procedures tijdens de binnenkomst indien enkel wordt gekeken naar die criteria die centraal staan binnen het enge kader van de procedurele rechtvaardigheidsliteratuur.

\section{Het belang van veiligheid en welzijn}

Het enge kader van de procedurele rechtvaardigheidsliteratuur blijkt echter te beperkt om de opvattingen van respondenten over de rechtvaardigheid van de uitvoering van de binnenkomstprocedure te begrijpen. Zij hechten namelijk meer belang aan twee aanvullende criteria dan aan de hiervoor besproken criteria.

Ten eerste wijzen de respondenten bij hun legitimiteitsopvatting op het belang van hun veiligheidsgevoelens en de wijze waarop deze gevoelens geborgd worden. Dit is deels in lijn met de bevindingen van Franke et al. en Tyler. ${ }^{68}$ Echter, waar strafrechtelijk gedetineerden veiligheid en de procedurele rechtvaardigheidscriteria als gelijkwaardig beschouwen, laten de geïnterviewde administratiefrechtelijke vreemdelingen zien dat het belang dat aan veiligheid wordt gehecht de procedurele rechtvaardigheidscriteria overstijgt. $\mathrm{Zij}$ hechten er veel waarde aan dat zowel 
zijzelf als hun medegedetineerden veilig zijn in het detentiecentrum. Ze benoemen hierbij vooral aspecten als de bescherming tegen bedreigend en onvoorspelbaar gedrag van medegedetineerden, het ongewenst binnentreden van hun cel door andere gedetineerden en de mogelijkheid zich af te schermen. Daarnaast gaan zij in op fysieke aspecten van veiligheid, zoals het weren van gevaarlijke voorwerpen, het belang van brandwerende deuren en bescherming in geval van calamiteiten. Een enkele respondent verwijst in dit opzicht naar de brand in het cellencomplex van detentiecentrum Schiphol waarbij in 2005 elf vreemdelingen het leven lieten. Respondenten benadrukken dat zij afhankelijk zijn van de DJImedewerkers dat dergelijke calamiteiten zich niet nogmaals voordoen. Het belang dat respondenten hechten aan hun veiligheid maakt dat zij eventueel ongemak van controles accepteren. Zo ook een Nigeriaanse respondent die vertelt het niet fijn te vinden dat DJI-medewerkers hem en zijn eigendommen controleerden, maar dit vanwege zijn veiligheid te accepteren:

'Anything for keeping us safe. You have to be treated with maximum security. What they are doing is fantastic in terms of security. [...] A person should be offered safety. They want to create a safe situation here, free from weapons and disorder. This is good.' - Oni.

Ook andere respondenten bevestigen dat zij controles en inperkingen van hun privacy accepteren als DJI-medewerkers hiermee hun veiligheid kunnen waarborgen. Het is naar hun idee de verantwoordelijkheid van DJI-medewerkers om ongelukken in het detentiecentrum te voorkomen. De genoemde acceptatie geldt echter niet voor inperking van hun vrijheid. Dit laat de precaire balans zien bij het inperken van de rechten van ingeslotenen ten behoeve van de veiligheid. Volgens sommigen mag de vrijheid van vreemdelingen afkomstig uit een PI wel worden ingeperkt nu zij onveiligheidsgevoelens van andere vreemdelingen zouden vergroten.

Ten tweede benadrukken de respondenten het belang van goede zorg voor hun lichamelijk en psychisch welzijn bij het beoordelen van de legitimiteit van de binnenkomstprocedure. Zij verwachten dat DJI-medewerkers zorgen voor hun lichamelijk welzijn middels het voorzien in materiële levensbehoeften, zoals eten, drinken en kleding. Daarnaast wensen zij ondersteuning in het kader van hun psychisch welzijn, ofwel het bieden van psychische ondersteuning en verlichting om hun angst te controleren en verminderen. Enigszins in tegenspraak met hun positieve oordeel over de binnenkomstprocedure vertellen de respondenten namelijk dat zij verschillende psychische en fysieke ongemakken - zoals onder meer paniekaanvallen, zweten en vergeetachtigheid - hebben ervaren tijdens hun binnenkomstprocedure. Deze worden volgens hen veroorzaakt door de opgelegde inbewaringstelling en de stress, onwetendheid en het onzekere toekomstperspectief dat hiermee gepaard gaat. Dit geldt ook voor een 43-jarige Ethiopische respondent die - voor hem - onverwachts en zonder uitleg door de politie in het azc werd opgehaald en in bewaring geplaatst werd. $\mathrm{Nu}$ hij in een afhankelijkheidspositie verkeert en geen controle meer heeft op zijn procedures of toekomst, verwacht hij dat de DJI-medewerkers zorgdragen voor zijn welbevinden door goede 
faciliteiten, detentieomstandigheden en aanwezige zorg. In tegenstelling tot wat bekend is over het borgen van de gezondheid tijdens - langdurig - verblijf in vreemdelingenbewaring, ${ }^{69}$ zijn respondenten over het algemeen positief over de mate waarin DJI-medewerkers tijdens de binnenkomstprocedure in hun welzijn en zorgbehoeften voorzien. Dit baseren de respondenten op de persoonlijke aandacht voor eventuele ongemakken, het aanbod van voeding en kleding, en de mogelijkheid voor psychische ondersteuning. Daarnaast geven ze aan dat DJImedewerkers gedurende deze procedure interesse tonen in hun gevoelens en emoties, hen geruststellen indien nodig en hen als 'human beings' behandelen. ${ }^{70}$

Ook strafrechtelijk gedetineerden benadrukken het belang van het borgen van hun veiligheid en welzijn om tot ervaren procedurele rechtvaardigheid en legitimiteit te komen. ${ }^{71}$ Waar strafrechtelijk gedetineerden evenveel waarde lijken te hechten aan de aanvullende criteria als aan de bestaande criteria van procedurele rechtvaardigheid, ${ }^{72}$ blijkt uit dit onderzoek dat de administratiefrechtelijk gedetineerden de nadruk leggen op deze aanvullende criteria. Naar ons idee kan dit worden verklaard vanuit het referentiekader van de gedetineerde vreemdelingen, en meer in het bijzonder de gedepriveerde en onzekere situatie van administratiefrechtelijk gedetineerde vreemdelingen in vergelijking met strafrechtelijk gedetineerden. Administratiefrechtelijk gedetineerde vreemdelingen worden tijdens hun onrechtmatig verblijf blootgesteld aan wat Kox, Boone en Staring 'the pains of being unauthorized' 73 noemen en verkeren veelal vanaf het moment van migratie tot aan het verblijf in vreemdelingenbewaring in onzekerheid waarbij zij - voor hun gevoel - de benodigde bescherming missen. Dit - en het idee dat zij de bewaring niet verdienen - maakt dat administratiefrechtelijk gedetineerde vreemdelingen het gevoel hebben relatief zwaar 'bestraft' te worden. ${ }^{74} \mathrm{Nu}$ Bottoms, Sparks en Hay stellen dat het belang van houvast toeneemt in een onvoorspelbare en gedepriveerde omgeving waarin iemand afhankelijk is van autoriteiten ${ }^{75}$ - zoals in een gevangenissetting het geval is - lijkt dit om deze redenen voor administratiefrechtelijk gedetineerden nog meer te gelden dan voor strafrechtelijk gedetineerden. Immers, deze vreemdelingen zijn - in hun gedepriveerde situatie - afhankelijk van de Nederlandse autoriteiten, de autoriteiten van

69 Stichting LOS, Amnesty International \& Dokters van de Wereld, 'Een ongezonde wet. Gezondheidszorgen \& Wet terugkeer en vreemdelingenbewaring', Amsterdam: Amnesty Nederland 2018.

70 Waar deze nieuwe criteria parallellen vertonen met het criterium 'belangenbehartiging' dat Leventhal (1980: 27-55) benoemt als onderdeel van zijn procedurele rechtvaardigheidstheorie, gaat dit verder, omdat het hier niet ziet op juridische belangen. Dit zou tekortdoen aan de nadruk die de geïnterviewde vreemdelingen op het borgen van hun veiligheid en gezondheid leggen.

71 Franke, et al. 2010, 89-117; Tyler 2010, 127-134; Bottoms 1999.

72 Idem.

73 M. Kox, M. Boone \& R. Staring, 'The pains of being unauthorized in the Netherlands', Punishment \& Society 2020, 22(4), 534-552. DOI: 10.1177/1462474519887357.

74 Idem. Kox, 2007, 186-193; 2011; Leerkes \& Kox, 2017, 895-929.

75 A.E. Bottoms, W. Hay \& J.R. Sparks, 'Situational and Social Approaches to the Prevention of Disorder in Long-term Prisons', The Prison Journal 1990, 80(1), 83-95. 
hun herkomstland en de onderlinge verhoudingen tussen deze autoriteiten. ${ }^{76}$ Dit plaatst de vreemdelingen in een onvoorspelbare en afhankelijke positie en verklaart mogelijkerwijs waarom zij meer belang hechten aan de bescherming van hun sociale en fysieke veiligheid en welzijn. Het laat zien dat bestaande criteria zoals onder andere aangedragen door Leventhal en Tyler - bij de oordeelsvorming over de uitvoering van de procedures in de context van administratiefrechtelijke vrijheidsontneming ontoereikend zijn.

\section{De pijn van inbewaringstelling}

Hoewel de - uitvoering van de - binnenkomstprocedure door respondenten als legitiem wordt ervaren, verandert dit positieve oordeel over de binnenkomstprocedure als buiten het enge kader van procedurele rechtvaardigheid wordt gekeken. Respondenten brengen namelijk gevoelens van pijn, onvrede en frustratie naar voren zodra de inbewaringstelling zelf ter sprake komt. Een respondent uit Bangladesh wordt bijvoorbeeld boos als hij het heeft over de rechtvaardigheid van de binnenkomstprocedure:

'Moral? I'm in jail, there is nothing moral about that. I don't care about this procedure. I ask for help [asielaanvraag] and you put me in jail. It's not fair you know. It's illegal. If you ask me my morals, I would say to be free.' - Atif.

De ervaren illegitimiteit van de inbewaringstelling was voor een paar respondenten reden zich te verzetten bij de binnenkomstprocedure. Zij weigerden bijvoorbeeld mee te werken aan de controles en/of bleven DJI-medewerkers aanstaren. In overeenstemming met de bevindingen van Alphen et $a{ }^{.77}$ staakten de betreffende respondenten hun verzet op het moment dat DJI-medewerkers het gesprek met hen aangingen en aandacht aan de persoonlijke situatie van de respondent besteedden. Zo ook een 24-jarige Nigeriaanse man die - voor hem - onverwachts in een azc was opgehaald en in Rotterdam in bewaring was gesteld. Hij vertelt dat hij die dag zou terugvliegen naar Nigeria en door zijn inbewaringstelling zijn zelf georganiseerde - vlucht heeft gemist. Hij is zichtbaar boos tijdens de binnenkomstprocedure waarna de situatie escaleert. Hij krijgt een woede-uitbarsting en staakt zijn medewerking aan de procedure. Hij werpt vooral vragen op over de rechtvaardigheid van zijn bewaring nu hij bezig was om zelfstandig zijn vertrek uit Nederland te realiseren. Hierop neemt de DJI-medewerker de respondent apart om naar diens verhaal te luisteren en hem te informeren over het verdere verloop van de procedure. Dit resulteert erin dat de respondent rustiger wordt, de controles accepteert en alsnog aan de procedures meewerkt. Later vertelt hij dat hij de binnenkomstprocedure rechtvaardig vindt, iets dat - in lijn met de procedurele rechtvaardigheidstheorie - invloed heeft gehad op zijn medewerkingsbe-

76 A.S. Leerkes \& M.H. Kox, 'Pressured into deportation? Detainees' (un)willingness to 'return' and the moderating influence of international relations', in: R. Furman, D. Epps \& G. Lamphear (red.), Detaining the Immigrant Other: Global and Transnational Issues, New York: Oxford University Press 2016, p. 15-26.

77 Alphen et al. 2013. 
reidheid aan de binnenkomstprocedure. ${ }^{78}$ Tegelijkertijd voorkomt dit niet dat hij de vrijheidsontneming op zichzelf illegitiem en onbegrijpelijk acht.

Naast verzet bij de binnenkomstprocedure zorgde de ervaren illegitimiteit van de inbewaringstelling ook voor uiteenlopende emotionele reacties, frustratie en schrik. Dit komt bijvoorbeeld naar voren bij de observatie van de binnenkomstprocedure van een 30 -jarige Surinaamse man. Hij moest voortdurend huilen en was niet in staat de vragen van DJI-medewerkers te beantwoorden. Een vriend die tegelijkertijd met deze man was binnengebracht heeft hem hiermee geholpen waarna de man - nog steeds huilend - naar zijn cel is gebracht. Tijdens het interview vertelt deze man dat zijn emoties werden veroorzaakt door het besef van de inbewaringstelling. Hoewel hij positief te spreken was over de bejegening en uitvoering van zijn binnenkomstprocedure door de DJI-medewerkers, overheerste voor hem het gevoel dat hem met zijn inbewaringstelling onrecht aangedaan is, omdat hij opgesloten zit zonder een strafbaar feit gepleegd te hebben.

Waar een klein deel van de respondenten aangeeft de vreemdelingenbewaring te accepteren en - naar eigen zeggen - het risico op deze mogelijkheid te hebben genomen, geldt dit niet voor de meerderheid. Hun opvattingen raken aan 'the pain of perceived illegitimacy' die Leerkes en Kox ${ }^{79}$ beschrijven nu een deel van deze respondenten meent dat zij de inbewaringstelling niet hebben verdiend daar zij geen strafbaar feit hebben gepleegd. Dit werd tijdens de observaties zichtbaar doordat respondenten tijdens hun registratie zowel hun onvrede met de inbewaringstelling tegenover DJI-medewerkers uitspraken of schreeuwden, als op rustige toon kritische vragen stelden over de inbewaringstelling. De strekking hiervan was steeds dezelfde: respondenten stelden geen crimineel te zijn en een verblijf in vreemdelingenbewaring niet te verdienen, zeker niet als zij zelf al bezig waren met hun vertrek uit Nederland. ${ }^{80}$ De onvrede met de inbewaringstelling en het beleid dat vreemdelingenbewaring voor mensen zonder verblijfsvergunning mogelijk maakt, weegt voor hen zwaarder dan hun oordeel over de rechtvaardig uitgevoerde binnenkomstprocedure.

\section{Conclusie en discussie}

Er bestaat veel empirische steun voor procedurele rechtvaardigheidstheorieën en Tyler - de grondlegger van het concept - is van mening dat procedurele rechtvaardigheid ook van belang is als substantiële belangen zoals vrijheidsontneming op het spel staan. ${ }^{81}$ Dit onderzoek laat zien dat de criteria zoals bekend in de procedurele rechtvaardigheidsliteratuur ook van belang zijn om tot een als rechtvaardig ervaren binnenkomstprocedure te komen, mits de veiligheid en het welzijn van vreemdelingen wordt geborgd. Echter, het concept procedurele rechtvaardigheid is in de context van vreemdelingenbewaring ontoereikend om de ervaren illegiti- 
miteit van vreemdelingenbewaring te begrijpen. ${ }^{82}$ Immers, het merendeel van de respondenten in dit onderzoek is van oordeel dat zij goed behandeld zijn in termen van procedurele rechtvaardigheid, maar vindt de vrijheidsontneming ter fine van uitzetting illegitiem. Deze respondenten menen dat zij het verblijf in vreemdelingenbewaring niet hebben verdiend en dat het immoreel is dat zij in bewaring worden geplaatst, te meer nu zij geen strafbaar feit hebben gepleegd. ${ }^{83}$ De ervaren procedurele rechtvaardigheid tijdens de binnenkomstprocedure in vreemdelingenbewaring brengt geen verandering in het negatieve oordeel van de meeste vreemdelingen over de legitimiteit van hun inbewaringstelling nu deze procedurele aspecten ondergeschikt zijn aan andere factoren.

Dit roept de vraag op wat ervaren procedurele rechtvaardigheid bijdraagt aan de perceptie van legitimiteit en wat voor factoren hierbij van belang zijn als - zoals in de context van vreemdelingenbewaring - substantiële belangen op het spel staan. Waar Skitka in de context van uitzettingen vanuit de VS stelt dat 'fair procedures do not ameliorate the sense of injustice people experience when a morally mandated outcome is threatened or rejected', ${ }^{84}$ is een dergelijke focus op uitkomsten naar ons idee hier onvoldoende. Het gebrek aan ervaren legitimiteit wordt namelijk vooral veroorzaakt door het gebrek aan gedeelde waarden over het gebruik van vreemdelingenbewaring van de Nederlandse autoriteiten enerzijds en de geïnterviewde vreemdelingen anderzijds. De Nederlandse autoriteiten menen dat het gebruik van vreemdelingenbewaring overeenkomstig Nederlandse wet- en regelgeving is en zien het als een noodzakelijk onderdeel van een streng maar rechtvaardig vreemdelingenbeleid. ${ }^{85}$ Het merendeel van de geïnterviewde vreemdelingen vindt het gebruik van een dergelijke vrijheidsontnemende maatregel onder sobere omstandigheden echter pijnlijk, onverdiend en onnodig. Dit is in lijn met de bevindingen van Bosworth die in de Britse context laat zien dat de opvattingen van de vreemdelingen over de legitimiteit van vreemdelingenbewaring afwijken van de opvattingen van de autoriteiten, wat ook hier resulteert in een legitimiteitstekort voor vreemdelingenbewaring. ${ }^{86}$ In de Nederlandse context zien wij meer differentiatie, ${ }^{87}$ maar ook hier stelt het merendeel van de gedetineerde vreemdelingen de legitimiteit van vreemdelingenbewaring ter discussie. Dit brengt ons tot de conclusie dat - zolang er fundamenteel verschillende percepties bestaan over de legitimiteit van het beleid waaraan iemand onderworpen wordt zoals bij het gebruik van vreemdelingenbewaring het geval is - het inrichten en uitvoeren van op zichzelf rechtvaardige procedures, interacties en uitkomsten onvoldoende is voor vreemdelingen om vreemdelingenbewaring als legitiem te ervaren. Gezien het belang van kennis over de percepties van legitimiteit van

82 Zie ook Kox, in ontwikkeling.

83 Leerkes \& Kox 2017, 895-929

84 L.J. Skitka, 'Do the means always justify the ends, or do the ends sometimes justify the means? A value protection model of justice reasoning', Personality and Social Psychology Bulletin 2002: 594, 28(5), 588-597.

85 Kamerstukken II 2010/11, 19637, nr. 1435, p. 1; Kamerstukken II 2013, Vergadering 77e: 'Rapport zelfmoord gedetineerde'; Kamerstukken II 2012/13, 19637, nr. 1630, p. 1566.

86 Bosworth 2013, 149-165.

87 Zie ook Kox, in ontwikkeling. 
degenen op wie het beleid zich richt, vereist dit - zeker in de huidige globaliserende context ${ }^{88}$ - ook een onderzoeksvraag en theoretisch kader waarbij voor deze bredere opvattingen van legitimiteit op zowel beleids- als uitvoerend niveau ruimte is. 